Primary research

\title{
Quantitation of Pseudomonas aeruginosa in wound biopsy samples: from bacterial culture to rapid 'real-time' polymerase chain reaction
}

\author{
Jean-Paul Pirnay ${ }^{\star \dagger}$, Daniel De Vos ${ }^{\dagger \neq}$, Luc Duinslaeger ${ }^{\star}$, Pascal Reper ${ }^{\star}$, \\ Christian Vandenvelde* ${ }^{*}$ Pierre Cornelis ${ }^{\dagger}$ and Alain Vanderkelen* \\ ${ }^{*}$ Queen Astrid Military Hospital, Neder-Over-Heembeek, ${ }^{\dagger}$ Flanders Interuniversity Institute of \\ Biotechnology, Sint-Genesius-Rode, and \#Innogenetics, Neder-Over-Heembeek, Belgium
}

Received: 9 January 2000

Crit Care 2000, 4:255-261

Revisions requested: 29 February 2000

Revisions received: 8 June 2000

Accepted: 14 June 2000

Published: 7 July 2000

(c) Current Science Ltd

\begin{abstract}
Statement of findings
We developed a real-time detection (RTD) polymerase chain reaction (PCR) with rapid thermal cycling to detect and quantify Pseudomonas aeruginosa in wound biopsy samples. This method produced a linear quantitative detection range of 7 logs, with a lower detection limit of $10^{3}$ colony-forming units (CFU)/g tissue or a few copies per reaction. The time from sample collection to result was less than $1 \mathrm{~h}$. RTD-PCR has potential for rapid quantitative detection of pathogens in critical care patients, enabling early and individualized treatment.
\end{abstract}

Keywords: burn wound, polymerase chain reaction, Pseudomonas aeruginosa, quantitation, sepsis

\section{Synopsis}

Introduction: Early diagnosis of wound colonisation or prediction of wound sepsis provides an opportunity for therapeutic intervention. There is need for qualitative and quantitative tests that are more rapid than bacterial culture. Pseudomonas aeruginosa results in high morbidity and mortality rates, is inherently resistant to common antibiotics, and is increasingly being isolated as a nosocomial pathogen. We developed three PCR-based methods to detect and quantify $P$ aeruginosa in wound biopsy samples: conventional PCR, enzyme-linked immunosorbent assay (ELISA)-PCR, and RTD-PCR with rapid thermal cycling (LightCycler ${ }^{\mathrm{TM}}$ technology), all based on the amplification of the outer membrane lipoprotein gene oprL. We compared the efficacy of these methods to bacterial culture by quantitatively measuring levels of $P$ aeruginosa in serial dilutions, in reconstituted skin samples and 21 burn wound biopsy samples.

Materials and methods: Serial 10-fold dilutions were made from an overnight $P$ aeruginosa culture and plated out onto Luria-Bertani and cetrimide agar plates. The agar plates were incubated overnight at $37^{\circ} \mathrm{C}$, and the colonies were counted in order to estimate the number of CFU per dilution tube. A sample was taken from each dilution tube as a template for the three PCR-based methods.

Serial $P$ aeruginosa dilutions (see above) were added to uninfected cadaveric skin. The reconstituted biopsy samples were homogenized using a tissue tearer and DNA was extracted using XTRAX DNA buffer. The DNA was resuspended in distilled water. A sample was taken as a template for the PCR-based methods.

Twenty-one burn wound biopsy samples were taken from nine patients with suspected $P$ aeruginosa burn wound infection. The biopsy samples were longitudinally divided into two pieces. From one piece, DNA was extracted (using XTRAX DNA buffer) and used as a template for PCR-based techniques (see above). The other piece was homogenized, in physiological water, using a tissue tearer. Serial 10-fold dilutions of the suspension were spread on Luria-Bertani and cetrimide agar plates. Colony counts were performed after overnight incubation at $37^{\circ} \mathrm{C}$.

The PCR mixture contained sterile distilled water, PCR buffer, deoxynucleotide mixture or digoxigenin labelling mix, $\mathrm{MgCl}_{2}$, diluted template, primers PAL1 and PAL2, and AmpliTaO DNA polymerase. The amplification was performed in a GeneAmp ${ }^{\circledR}$

$\mathrm{CFU}=$ colony-forming units; ELISA = enzyme-linked immunosorbent assay; EtBr = ethidium bromide; $\mathrm{MTP}=$ microtitre plate; $\mathrm{PCR}=$ polymerase chain reaction; RTD = real-time detection. 
PCR System 2400. An aliquot of the reaction mixture was put on an agarose gel for electrophoresis and visualisation of the PCR product. An image of the gel was made using a digital camera. Image analysis software was used to calculate the band mass of the experimental bands.

An aliquot of the digoxigenin labelling reaction was denatured and then hybridized with the biotinylated capture probe PrL. Some of the resultant solution was transferred to a well of a streptavidin-coated microtitre plate (MTP) and incubated for $3 \mathrm{~h}$ at $45^{\circ} \mathrm{C}$. The solution was discarded. Peroxidase conjugated antidigoxigenin was added and the MTP was incubated for $30 \mathrm{~min}$ at $37^{\circ} \mathrm{C}$. The solution was discarded and ABTS substrate was added. The MTP was incubated for $30 \mathrm{~min}$ at $37^{\circ} \mathrm{C}$. Absorbance was read at $405 \mathrm{~nm}$.

The RTD-PCR mixture contained PCR grade sterile water, diluted template DNA, primers PAL1 and PAL2, 3' fluorescein (FL)-labelled probe oprL-FL, 5' LC Red 640-labelled and 3' phosphorylated probe oprL-LC, $\mathrm{MgCl}_{2}$, and LC DNA Master Hybridisation Probes, containing Taq DNA polymerase, reaction buffer, dNTP mix with dUTP instead of dTTP and, $\mathrm{MgCl}_{2}$. The amplification was performed in a LightCycler ${ }^{\mathrm{TM}}$. The fluorescence signal of LC Red 640 was measured during the annealing phase. The measured fluorescence data was processed with analysis software.

Results and discussion: The three methods showed a good concordance with the culture results. Conventional PCR was at least 100 times less sensitive than bacterial culture and had a low dynamic range (2 logs). With a lower detection limit of $10^{3} \mathrm{CFU} / \mathrm{g}$ tissue, ELISA-PCR was ten times more sensitive than conventional PCR. The dynamic range, however, did not increase. ELISA-PCR is very time consuming $(8 \mathrm{~h})$. The RTDPCR produced a linear quantitative detection range of 7 logs with a lower detection limit of $10^{3} \mathrm{CFU} / \mathrm{g}$ tissue. More important, however, was that the time from sample collection to result was less than $1 \mathrm{~h}$. Two biopsy specimen scored significantly higher in ELISA-PCR and RTD-PCR than in bacterial culture. This could indicate that DNA from dead bacteria was amplified. One out of ten culture positive biopsy samples was found negative by all PCR-based methods. Topical antimicrobial agents possibly inhibited PCR. These results show that RTD-PCR has potential for the rapid quantitative detection of pathogens in critical care patients, enabling early and individualized treatment. Further study is required to assess the reliability of this new technology, and its impact on patient outcome and hospital costs.

\section{Full article}

\section{Introduction}

Although effective topical antimicrobial chemotherapy and early excision of burn wounds have significantly reduced the occurrence of invasive burn wound infections, sepsis is still a major problem [1-3]. The risk of septicaemia increases in proportion to the degree of cutaneous infection [4-6]. Many investigators have reported [6-11] that quantitative biopsy culture was the best method for early detection of sepsis. Heininger et al [12] stressed that only $4-12 \%$ of blood cultures is found positive. Conversely, McManus et al [13] reported in 1987 that high tissue counts did not necessarily indicate invasion, and that the principal value of quantitative biopsy culture was the demonstration of the predominant burn wound flora. Even so, when sepsis ensues, while awaiting the results of blood cultures, a knowledge of the organisms that colonize a burn wound can facilitate prompt and appropriate antibiotic treatment that is based on the expected sensitivity of the identified germs, rather than initiating a purely empirical therapy. There is need for qualitative and quantitative tests that are more rapid than bacterial culture.

We decided to develop such a test for the rapid detection and quantitation of Pseudomonas aeruginosa in burn wound biopsy samples. This bacterium is ubiquitous, is inherently resistant to common antibiotics, and therefore is one of the most problematic pathogens in modern hospitals
[14-17]. Burn wound patients, mechanically ventilated patients and cystic fibrosis patients are particularly susceptible to $P$ aeruginosa infection $[1,18,19]$. Biopsy samples are, with respect to homogenization and DNA extraction, very tough clinical samples and thus would be an excellent test case for the applicability of the method on direct clinical samples.

In 1997 our group developed a PCR test for the direct detection and identification of $P$ aeruginosa in clinical samples that is based on the amplification of the outer membrane lipoprotein gene oprL [20-22]. Since then we developed several quantitative variants of this test, exploiting the technology available at the time.

In the first instance, we amplified the oprL gene by means of conventional PCR and visualized the PCR product by ethidium bromide $(\mathrm{EtBr})$ staining of agarose gels. The intensity of the fluorescence produced by $\mathrm{EtBr}$ was quantified.

Second, we developed an ELISA-mediated PCR in order to quantify the amplified oprL gene. PCR products were labelled with digoxigenin during the amplification process and quantitatively detected by absorbance reading in microtitre plates.

Finally, we exploited the recently developed 'real-time' quantitative PCR technology [23-27]. We opted for the 
LightCycler $^{\mathrm{TM}}$ [28] system (Roche Diagnostics, Brussels, Belgium) because it features rapid capillary tube resistive thermal cycling, reducing the amplification time dramatically. Two adjacent hybridization probes, labelled with different fluorescent dyes, are used to monitor the appearance of PCR product. The emitted light signal is proportional to the amount of specific DNA product available for hybridization, and thus increases every cycle [29]. The probes were designed to be complementary to a conserved region of the oprL gene, as determined by sequence analysis of the opr $L$ gene of 85 nonrelated clinical $P$ aeruginosa isolates.

In the present report we compare the assay performance of the above-mentioned methods, in terms of practicability, to bacterial culture. For this purpose three types of samples were assayed: serial $P$ aeruginosa dilutions, uninfected skin spiked with $P$ aeruginosa and 21 burn wound biopsy samples. All methods were useful, but only LightCycler $^{\mathrm{TM}}$ RTD-PCR allowed rapid quantitative detection of $P$ aeruginosa in skin biopsies with an adequate detection limit and a wide log-linear range.

\section{Materials and methods Sample preparation}

Serial Pseudomonas aeruginosa dilutions

Serial 10-fold dilutions were made from an overnight $P$ aeruginosa culture (strain PAO-1, ATCC 15692) in order to look for the lower detection limit and the dynamic range of the PCR-based methods. Dilutions were made in physiological water. Aliquots $(100 \mu \mathrm{l})$ were plated out, in triplicate, onto Luria-Bertani (Gibco-BRL Life Technologies, Paisley, Scotland) and cetrimide (Sanofi Pasteur, Brussels, Belgium) agar plates. The agar plates were incubated overnight at $37^{\circ} \mathrm{C}$, and the colonies were counted in order to estimate the number of CFU per dilution tube. A sample $(5 \mu \mathrm{l})$ was taken from each dilution tube as a template for the three PCR-based methods. Standards ranging from 1 to $10^{6} \mathrm{CFU} / 5 \mu$ l were assayed.

\section{Reconstituted biopsy samples}

Reconstituted biopsy samples were prepared in sterile 5-ml tubes (Nunc; Roskilde, Denmark) by adding $10 \mu \mathrm{l}$ serial $P$ aeruginosa dilutions (see above) to $50 \mathrm{mg}$ uninfected cadaveric skin, at final concentrations of $10-10^{9} \mathrm{CFU} / \mathrm{g}$ tissue. XTRAX DNA extraction buffer $(1 \mathrm{ml}$; Gull Laboratories, Salt Lake City, UT, USA) was added, and the reconstituted biopsy samples were homogenized for $1 \mathrm{~min}$, at $30000 \mathrm{rpm}$, using a tissue tearer (BioSpec Products, Bartlesville, Oklahoma, USA). The suspensions were transferred to a 1.8-ml cryotube (Nunc) with a loosened cap and were microwaved for $13 \mathrm{~s}$ at $600 \mathrm{~W}$. The tubes were gently shaken to mix the contents and were microwaved for a further $6 \mathrm{~s}$. The tubes were cooled for $3 \mathrm{~min}$ at room temperature and centrifuged for $1 \mathrm{~min}$ at $10000 \mathrm{~g}$ in order to pellet the proteins.
Supernatant $(500 \mu \mathrm{l})$ was transferred to a microcentrifuge tube (Eppendorf, Hamburg, Germany). Molecular grade isopropanol $(500 \mu \mathrm{l}$; Sigma Aldrich, Deisenhofen, Germany) was added, and the contents of the tube were mixed thoroughly by inverting the tube 10 times. The tube was centrifuged for $1 \mathrm{~min}$ at $10000 \mathrm{~g}$ in order to pellet the DNA. The supernatant was discarded by decanting, and the tube was allowed to stand upside down for 2 min to allow the remaining fluid to drain. The DNA was resuspended in $30 \mu \mathrm{l}$ distilled water. A sample $(5 \mu \mathrm{l})$ was taken as a template for conventional PCR and ELISA-PCR, and $3 \mu \mathrm{l}$ was taken for RTD-PCR. Standards ranging from $10^{3}$ to $10^{9} \mathrm{CFU} / \mathrm{g}$ skin tissue were assayed.

Clinical burn wound biopsy samples

Twenty-one burn wound biopsy samples, weighing 20-170 mg (mean $54 \mathrm{mg}$ ), were assayed. The biopsy specimens were aseptically taken from nine patients with suspected $P$ aeruginosa burn wound infection, using a 4-mm punch biopsy needle (Labo Stiefel, Leuven, Belgium; $n=15)$ or a lancet $(n=6)$.

The samples were longitudinally divided into two pieces using a sterile scalpel and weighed. From one piece DNA was extracted using XTRAX DNA buffer and used as template for the PCR-based techniques (see above). The other piece was collected in a sterile 5-ml tube containing $10 \mu \mathrm{l}$ physiological water/mg tissue, and was homogenized, on ice, for $1 \mathrm{~min}$ at $30000 \mathrm{rpm}$ using a tissue tearer. Serial 10-fold dilutions of the homogenized wound biopsy samples were spread, in triplicate, on Luria-Bertani and cetrimide agar plates. Colony counts were performed after overnight incubation at $37^{\circ} \mathrm{C}$.

\section{Conventional polymerase chain reaction and digoxigenin labelling}

The PCR was completed in 200- $\mu$ l microcentrifuge tubes. The PCR mixture ( $50 \mu$ l final volume) contained the following: $26.5 \mu \mathrm{l}$ sterile distilled water; $5 \mu \mathrm{l} 10 \times \mathrm{PCR}$ buffer (500 mmol// KCl and $100 \mathrm{mmol} / \mathrm{l}$ Tris- $\mathrm{HCl}: \mathrm{pH} 8.3$ ); $5 \mu \mathrm{l}$ of a deoxynucleotide mixture (dGTP, dTTP, dATP and dCTP; $2 \mathrm{mmol} / \mathrm{l}$ each) or $5 \mu \mathrm{l}$ digoxigenin-labelling mix from Boehringer-Mannheim (Brussels, Belgium; $2 \mathrm{mmol} / \mathrm{l}$ dGTP, dATP and dCTP, and $1.9 \mathrm{mmol} / /$ digoxigenindUTP); $6 \mu \mathrm{MgCl}_{2}(2.5 \mathrm{mmol} / \mathrm{l}) ; 5 \mu \mathrm{l}$ diluted template DNA; $1 \mu \mathrm{l}$ primer PAL1 $(25 \mu \mathrm{mol} / \mathrm{l}) ; 1 \mu \mathrm{l}$ primer PAL2 $(25 \mu \mathrm{mol} / \mathrm{l}) ;$ and $0.5 \mu \mathrm{l}$ AmpliTaQ DNA polymerase $(5 \mathrm{U} / \mu \mathrm{l})$. The primers had the following sequences: PAL1, 5'-ATGGAAATGCTGAAATTCGGC-3'; and PAL2, 5'CTTCTTCAGCTCGACGCGACG-3'. All PCR reagents were purchased from PE Applied Biosystems (Nieuwerkerk a/d ljssel, The Netherlands).

A reaction mixture containing all of the ingredients except the template was made. The amplification was performed in a GeneAmp ${ }^{\circledR}$ PCR System 2400 (PE Applied Biosystems). 
The amplification program was set at 35 cycles of denaturation at $94^{\circ} \mathrm{C}$ for $30 \mathrm{~s}$ or $45 \mathrm{~s}$ (digoxigenin labelling), annealing at $57^{\circ} \mathrm{C}$ for $30 \mathrm{~s}$ or 1 min (digoxigenin labelling), and elongation at $72^{\circ} \mathrm{C}$ for $30 \mathrm{~s}$ or 2 min (digoxigenin labelling).

Some of the reaction mixture $(10 \mu l)$ was put on an agarose gel of $2 \%$ (weight/volume) for electrophoresis and visualization of the PCR product after staining with $\mathrm{EtBr}$ on a ultraviolet transilluminator. An image of the gel was made using a DC40 digital camera (Eastman Kodak Company, Rochester, New York, USA). Using the intensity measured for the bands originating from the standards, $P$ aeruginosa serial dilutions or reconstituted samples, Kodak Digital Science 1D image analysis software was used to calculate the band mass of the experimental bands using linear regression.

\section{Digoxigenin detection}

Some of the digoxigenin labelling reaction $(35 \mu \mathrm{l})$ was transferred to a sterile microcentrifuge tube (Eppendorf). Denaturation solution $(40 \mu \mathrm{l})$ was added and the tube was incubated for $10 \mathrm{~min}$ at room temperature. The tube was filled up to $500 \mu \mathrm{l}$ with hybridization solution, which contained $50 \mathrm{pmol} / \mathrm{ml}$ biotinylated capture probe $\operatorname{PrL}$ with the following sequence: 5'-AAGCCGGAAGCCATGCGCGCT-3'. Some of the resultant solution $(200 \mu \mathrm{l})$ was transferred to a well of a streptavidin-coated microtitre plate (MTP). The MTP was incubated for $3 \mathrm{~h}$ at $45^{\circ} \mathrm{C}$ on a MTP shaker. The solution was discarded and the well was washed five times with $250 \mu \mathrm{l}$ washing solution. A quantity $(200 \mu \mathrm{l})$ of a peroxidase conjugated antidigoxigenin solution $(10 \mathrm{mU} / \mathrm{ml})$ was added, and the MTP was incubated for $30 \mathrm{~min}$ at $37^{\circ} \mathrm{C}$ on a MTP shaker. The solution was discarded and the well was washed five times with washing solution. ABTS substrate solution $(200 \mu \mathrm{l})$ was added and the MTP was incubated for $30 \mathrm{~min}$ at $37^{\circ} \mathrm{C}$ on a MTP shaker. Absorbance was read at $405 \mathrm{~nm}$. All digoxigenin detection reagents were purchased from BoehringerMannheim.

\section{Real-time detection polymerase chain reaction}

The RTD-PCR mixture $(20 \mu$ final volume) contained the following: $3.8 \mu \mathrm{l}$ PCR grade sterile water; $3 \mu \mathrm{l}$ diluted template DNA; $2 \mu$ l primer PAL1 $(5 \mu \mathrm{mol} / \mathrm{ll}) ; 2 \mu \mathrm{l}$ primer PAL2 $(5 \mu \mathrm{mol} / \mathrm{l}) ; 2 \mu \mathrm{l}$ of the $3^{\prime}$ fluorescein-labelled probe oprLFL $(2 \mu \mathrm{mol} / \mathrm{l}) ; 4 \mu \mathrm{l}$ of $5^{\prime}$ LC Red 640 -labelled and $3^{\prime}$ phosphorylated probe oprL-LC $(2 \mu \mathrm{mol} / \mathrm{l}) ; 1.2 \mu \mathrm{l} \quad \mathrm{MgCl}_{2}$ (25 mmol/l); $2 \mu \mathrm{l}$ LC DNA Master Hybridisation Probes containing Taq DNA polymerase; reaction buffer; dNTP mix with dUTP instead of dTTP; and $10 \mathrm{mmol} / / \mathrm{MgCl}_{2}$. All reagents were purchased from Roche Molecular Biochemicals (Brussels, Belgium). The probes were manufactured by the TIB MOLBIOL synthesis laboratory in Berlin, Germany, and had the following sequences: oprL-FL, 5'TGCGATCACCACCTTCTACTTCGAGT-FL-3'; and oprLLC, 5'-LC Red 640-CGACAGCTCCGACCTGAAG-p-3'.
Samples were spun into glass capillary tubes, capped and placed in the LightCycler ${ }^{\mathrm{TM}}$. After an initial denaturation at $95^{\circ} \mathrm{C}$ for $30 \mathrm{~s}$, amplification was performed for 45 cycles of denaturation at $95^{\circ} \mathrm{C}$ for $2 \mathrm{~s}$, annealing at $59^{\circ} \mathrm{C}$ for $10 \mathrm{~s}$ and elongation at $72^{\circ} \mathrm{C}$ for $10 \mathrm{~s}$. The fluorescence signal of LC Red 640 was measured during the annealing phase. The measured fluorescence data was processed with analysis software.

\section{Results and discussion}

\section{Conventional polymerase chain reaction}

With a lower detection level between $10^{4}$ and $10^{5} \mathrm{CFU} / \mathrm{g}$, wound biopsy tissue conventional PCR was at least 100 times less sensitive than bacterial culture (Table 1). This problem was related to the limited amount of sample, as compared with bacterial culture, that can be incorporated into one PCR reaction. Concentration of DNA or division of the sample over multiple PCR reactions could resolve this problem, but would result in a more elaborate method. Conventional PCR had a low dynamic range; bands that were very close to the background level gave poor results, and bands that were saturated also skewed the results (Fig. 1).

Ten out of 21 burn wound biopsy samples turned out to be culture positive; five of them, with a density lower than $10^{4} \mathrm{CFU} / \mathrm{g}$, were not detected by conventional PCR. All culture-negative samples were also negative in PCR.

\section{Enzyme-linked immunosorbent assay polymerase chain reaction}

With a detection limit of $10^{3} \mathrm{CFU} / \mathrm{g}$ tissue, ELISA-PCR was at least 10 times more sensitive than conventional PCR (Table 1). However, the linear response range did not increase, but shifted to lower concentrations along with the detection limit (Fig. 1). This technique is very time consuming and involves handling that increase the risk of contamination of PCR product (Fig. 2). Only one culturepositive wound biopsy, out of 10 , containing $3000 \mathrm{CFU} / \mathrm{g}$ tissue, was found to be negative by ELISA-PCR. Topical antimicrobial agents possibly inhibited PCR.

Two biopsy specimens with approximately 200 and $400 \mathrm{CFU} / \mathrm{g}$ tissue, as determined by bacterial culture, scored significantly higher in ELISA-PCR: 1200 and $1450 \mathrm{CFU} / \mathrm{g}$ tissue, respectively. This could indicate that DNA from nonproliferating or dead bacteria was amplified. The question regarding whether quantitative estimates of bacteria, determined using PCR-based methods, correlate with the number of viable bacteria has been raised before [30]. For this reason, PCR-based tests are probably not appropriate for the monitoring of treatment efficacy. They should be considered as complementary indicative tests in critical care settings. On the other hand, PCR-based methods could detect bacteria that were inhibited in their growth by residual concentrations of antimicrobials in the sample [31], overgrown by other bacteria present in the 


\section{Conventional PCR}
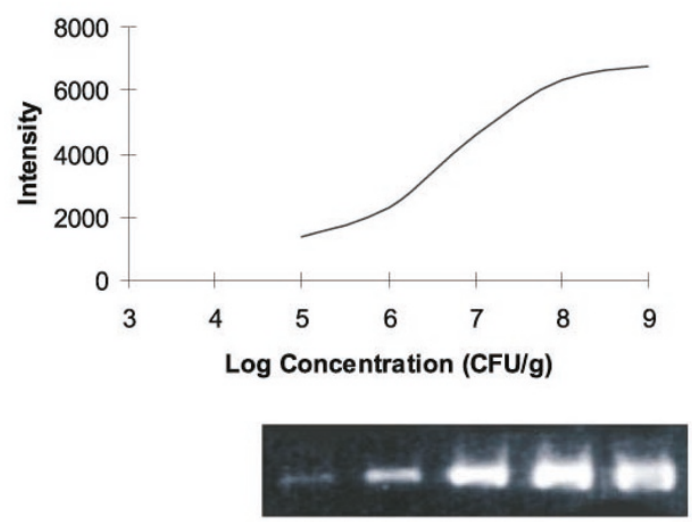

RTD-PCR

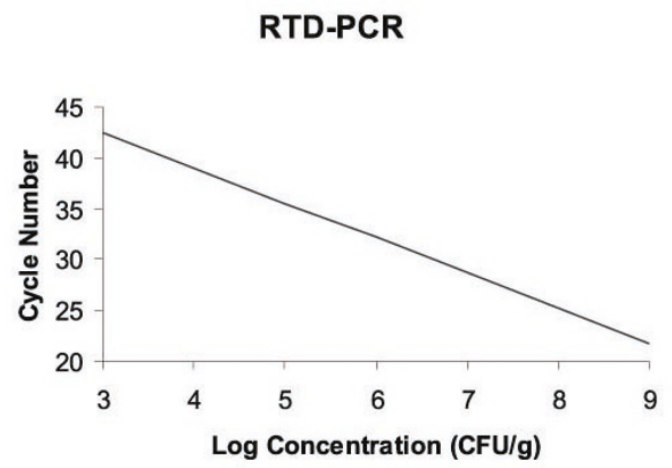

\section{ELISA-PCR}

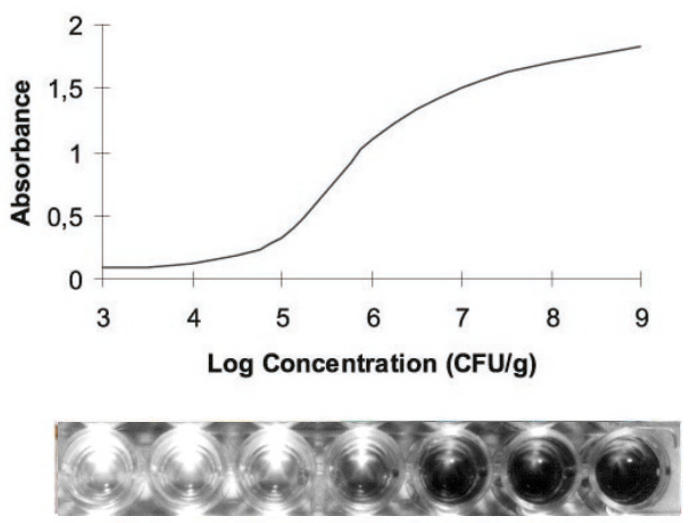

Standard curves for reconstituted biopsy samples.

sample, autolyzed during incubation [32], or difficult to cultivate in vitro [33], and are thus under-diagnosed by bacterial culture. PCR-ELISA has merit with regard to its sensitivity, but is too time-consuming and expensive to implement in a clinical laboratory (Fig. 2).

\section{Real-time detection polymerase chain reaction}

RTD-PCR produced a linear quantitative detection range of 7 logs with a lower detection limit of $10^{3} \mathrm{CFU} / \mathrm{g}$ tissue, or a few copies per reaction (Table 1). RTD-PCR uses a kinetic approach rather than an end-point approach. Kinetic quantification in the log phase of the reaction, the phase of constant efficiency, clearly generates a larger linear response than end-point detection in the plateau phase of the reaction (Fig. 1). Also, there is no need for any post-PCR sample manipulation, eliminating PCR contamination concerns. The recent introduction of a second dye for the LightCycler ${ }^{\mathrm{TM}}$ system offers the prospect of an internal control, addressing the problem of tube-to-tube variations and PCR inhibition, and thus improving the reliability of the results. However, the greatest merit of Light-
Cycler $^{T M}$ RTD-PCR is its rapidity. Rapid thermal cycling reduced the time of amplification, detection and analysis of DNA from several hours to $30 \mathrm{~min}$ (Fig. 2). The RTDPCR results for the burn wound biopsy samples were concordant with those obtained using ELISA-PCR; the false-negative result and the two over-diagnosed biopsies were also observed using RTD-PCR. The use of capillaries instead of tubes permits smaller reaction volumes, thus lowering the reagent costs. The set-up costs, however, may be beyond the capabilities of some laboratories (Table 1).

\section{Conclusion}

Up until now, RTD-PCR has been applied for the detection of food-borne pathogens [34], cancer [35-37], genetic diseases [38] and infectious diseases [39-42].

Although a limited number of clinical specimens were tested, the present results indicate that RTD-PCR, and more specifically LightCycler ${ }^{\mathrm{TM}}$ technology, has potential for quantitative applications in the clinical laboratory. In 
Table 1

Summary of the characteristics of the tested quantitation methods

\begin{tabular}{|c|c|c|c|c|c|c|c|}
\hline \multirow[b]{2}{*}{ Method } & \multicolumn{2}{|c|}{ Lower detection limit ${ }^{\star}$} & \multirow{2}{*}{$\begin{array}{l}\text { Log-linear range } \\
\quad(\mathrm{CFU} / \mathrm{g})\end{array}$} & \multirow[b]{2}{*}{ Time to result (h) } & \multirow[b]{2}{*}{ Ease of use } & \multirow{2}{*}{$\begin{array}{l}\text { Cost per test } \\
(\text { US } \$)^{\dagger}\end{array}$} & \multirow{2}{*}{$\begin{array}{l}\text { Set up } \\
\text { cost (\$) }\end{array}$} \\
\hline & (CFU/g) & (CFU/reaction) & & & & & \\
\hline Culture & $10^{2}$ & 1 & $10^{2}-10^{9}$ & 24 & Easy & 6 & 3500 \\
\hline PCR & $10^{4}-10^{5}$ & $10-10^{2}$ & $10^{6}-10^{8}$ & 4 & Moderate & $12^{\ddagger}$ & 20000 \\
\hline ELISA-PCR & $10^{3}-10^{4}$ & $1-10$ & $10^{5}-10^{7}$ & 8 & Elaborate & $25^{\ddagger}$ & 20000 \\
\hline RTD-PCR (LC) & $10^{3}-10^{4}$ & $1-10$ & $10^{3}-10^{9}$ & 1 & Moderate & $9^{\ddagger}$ & 73000 \\
\hline
\end{tabular}

*The lower detection limit is variable due to variations in inter-run amplification efficiency. ${ }^{+}$Not including labour costs, only reagents and disposables. ${ }^{\ddagger}$ Cost per clinical sample, based on the analysis of batches of 10 clinical samples and eight standards. LC, LightCycler ${ }^{\top \mathrm{T}}$.

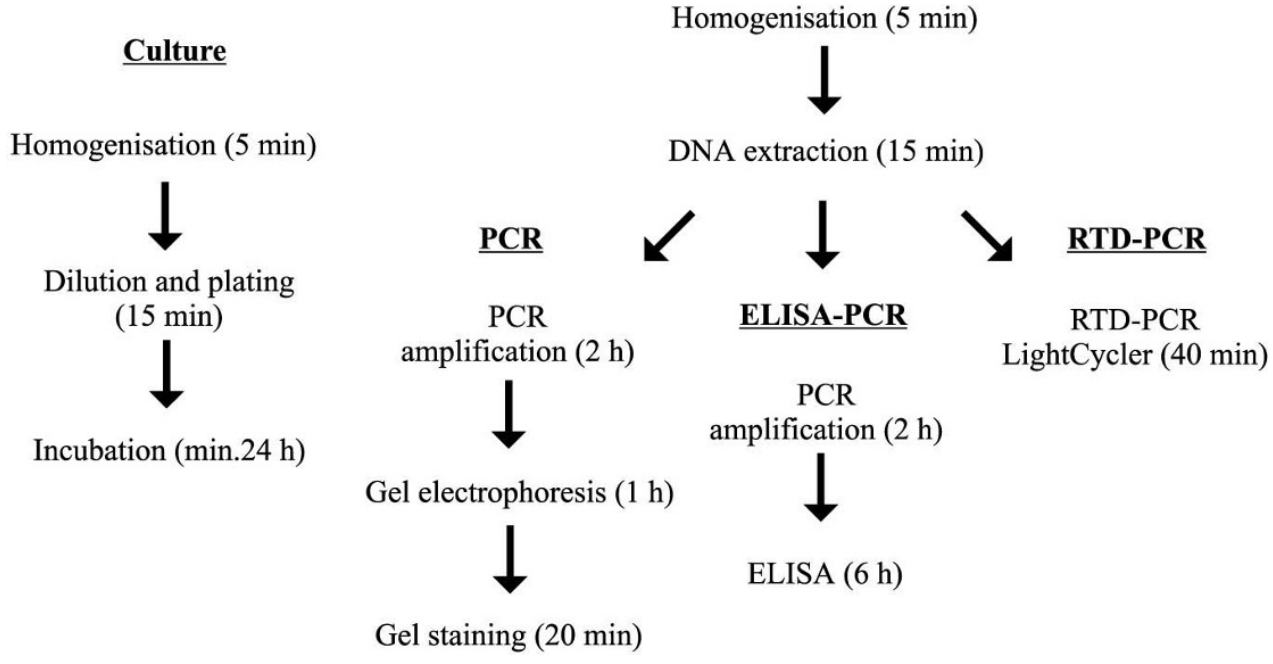

Comparison of the procedural steps involved in the quantitation methods.

particular, it has applications for the critical care population, at the point of care, and it is important that the test is subjected to further optimization and evaluation. Early infection diagnosis remains a difficult problem for patients with burn wounds or cystic fibrosis, and for critical care patients in general. Prognosis and survival are often dependent on an early, individualized treatment. Automated extraction of DNA from a variety of clinical samples (blood, expectorations, urine, etc.) and subsequent rapid, online, quantitative detection of pathogens ( $P$ aeruginosa, Staphylococcus aureus, Haemophilus influenzae, among others) by RTD-PCR is now possible, allowing early therapeutic decisions to be made. Multiple colour detection will open the door to multiplex RTD-PCR. Further studies are necessary to assess the impact of rapid RTD-PCR on patient outcome and hospital costs $[43,44]$.

\section{Acknowledgements}

This work was supported by grants of ESSO Benelux and VZW 'De Vrienden van de Huidbank'.

\section{References}

1. Pruitt BA Jr, McManus AT, Kim SH, Goodwin CW: Burn wound infections: current status. World J Surg 1998, 22:135-145.

2. Lee JJ, Marvin JA, Heimbach DM, Grube BJ, Engrave LH: Infection control in a burn center. J Burn Care Rehabil 1992, 11:575-580.

3. McManus AT, Mason AD Jr, McManus WF, Pruitt BA Jr: Twenty-five year review of Pseudomonas aeruginosa bacteremia in a burn center. Eur J Clin Microbiol 1985, 4:219-223.

4. Teplitz C, Davis D, Mason AD Jr, Moncrief JA: Pseudomonas burn wound sepsis. I. Pathogenesis of experimental Pseudomonas burn wound sepsis. J Surg Res 1964, 4:200-222.

5. Moncrief JA, Lindberg RB, Switzer WE, Pruitt BA Jr: Use of topical antibacterial therapy in the treatment of the burn wound. Arch Surg 1966, 92:558-565.

6. Perez-Cappelano R, Manelli JC, Palayret D, Carlin G, Echinard C Jouglard JP: Evaluation of the septicaemic risk by a quantitative study of the cutaneous flora in patients with burns. Burns 1976, 3:42-45. 
7. Lawrence JC, Lilly HA: A quantitative method for investigating the bacteriology of the skin: its applicability to burns. Br J Exp Pathol 1972, 53:550-558.

8. Loebl EC, Marvin JA, Heck EL, Curreri, PW, Baxter CR: The method of quantitative burn-wound biopsy cultures and its routine use in the care of the burned patient. Am J Clin Pathol 1974, 61:20-24.

9. McManus WF, Goodwin CW, Mason AD Jr, Pruitt BA Jr: Burn wound infection. J Trauma 1981, 21:753-756.

10. Taddonio TE, Thomson PD, Tait MJ, Prasad JK, Feller I: Rapid quantification of bacterial and fungal growth in burn wounds: biopsy homogenate Gram stain versus microbial culture results. Burns 1988, 14:180-184.

11. Bharadwaj R, Joshi BN, Phadke SA: Assessment of burn wound sepsis by swab, full thickness biopsy culture and blood culture: a comparative study. Burns 1983, 10:124-126.

12. Heininger $A$, Binder M, Schmidt $S$, Unertl K, Botzenhart K, Döring G: PCR and blood culture for detection of Escherichia coli bacteremia in rats. $J$ Clin Microbiol 1999, 37:2479-2482.

13. McManus AT, Kim SH, McManus WF, Mason AD Jr, Pruitt BA Jr: Comparison of quantitative microbiology and histopathology in divided burn-wound biopsy specimens. Arch Surg 1987, 122: 74-76.

14. Masuda N, Sakagawa E, Ohya S: Outer membrane proteins responsible for multiple drug resistance in Pseudomonas aeruginosa. Antimicrob Agents Chemother 1995, 39:645-649.

15. Nikaido $\mathrm{H}$ : Prevention of drug access to bacterial targets: permeability barriers and active efflux. Science 1994, 264:382-388.

16. Burdon DW, Whitby JL: Contamination of hospital disinfectants with Pseudomonas species. BrMed J 1967, 2:153-155.

17. Parrott PL, Terry PM, Whitworth EN, Frawley LW, Coble RS, Wachsmuth IK, McGowan JE Jr: Pseudomonas aeruginosa peritonitis associated with contaminated poloxamer-iodine solution. Lancet 1982, ii:683-685.

18. Craven DE, Steger KA: Nosocomial pneumonia in mechanically ventilated adult patients: epidemiology and prevention in 1996. Semin Respir Infect 1996, 11:32-53.

19. Koch C, Høiby N: Pathogenesis of cystic fibrosis. Lancet 1993, 341: 1065-1069.

20. Cornelis P, Bouia A, Belarbi A, Guyonvarch A, Kammerer B, Hannaert V, Hubert JC: Cloning and analysis of the gene for the major outer membrane lipoprotein from Pseudomonas aeruginosa. Mol Microbiol 1989, 3:421-428.

21. Lim A Jr, De Vos D, Brauns M, Mossialos D, Gaballa A, Qing D, Cornelis $P$ : Molecular and immunological characterization of OprL, the 18-kDa outer membrane peptidoglycan-associated (PAL) lipoprotein of Pseudomonas aeruginosa. Microbiology 1997, 143:17091716

22. De Vos D, Lim A Jr, Pirnay JP, Struelens M, Vandenvelde C, Duinslaeger L, Vanderkelen A, Cornelis P: Direct detection of Pseudomonas aeruginosa in clinical samples such as skin biopsy specimens and expectorations by multiplex PCR based on two outer membrane lipoprotein genes, oprl and oprL. J Clin Microbiol 1997, 35:1295-1299.

23. Holland PM, Abramson RD, Watson R, Gelfand DH: Detection of specific polymerase chain reaction product by utilizing the $5^{\prime}-3^{\prime}$ exonuclease activity of Thermus aquaticus DNA polymerase. Proc Natl Acad Sci USA 1991, 88:7276-7280.

24. Tyagi S, Kramer FR: Molecular beacons: probes that fluoresce upon hybridization. Nature Biotechnol 1996, 14:303-308.

25. Wittwer CT, Herrmann MG, Moss AA, Rasmussen RP: Continuous fluorescence monitoring of rapid cycle DNA amplifications. BioTechniques 1997, 22:130-138.

26. Nazarenko IA, Bhatnagar SK, Hohman RJ: A closed tube format for amplification and detection of DNA based on energy transfer. Nucleic Acids Res 1997, 25:2516-2521.

27. Whitcombe D, Theaker J, Guy SP, Brown T, Little S: Detection of PCR products using self-probing amplicons and fluorescence. Nature Biotechnol 1999, 17:804-807.

28. Wittwer C, Ririe K, Andrew R, David D, Gundry R, Balis U: The LightCycler $^{\mathrm{TM}}$ : a microvolume multisample fluorimeter with rapid temperature control. BioTechniques 1997, 22:176-181.

29. Livak KJ, Flood SJA, Marmaro J, Giusti W, Deetz K: Oligonucleotides with fluorescent dyes at opposite ends provide a quenched probe system useful for detecting PCR product and nucleic acid hybridization. PCR Methods Appl 1995, 4:357-362.

30. Desjardin LE, Chen Y, Perkins MD, Teixeira L, Cave MD, Eisenach KD: Comparison of the $\mathrm{ABI} 7700$ system (TaqMan) and competitive
PCR for quantification of IS6110 DNA in sputum during treatment of tuberculosis. J Clin Microbiol 1998, 36:1964-1968.

31. Matsumoto T, Tanaka M, Ogata N, Mizunoe Y, Takahashi K, Kumazawa $\mathrm{J}$ : Significance of urinary endotoxin concentration in patients with urinary tract infection. Urol Res 1991, 19:293-295.

32. Fischer GW, Smith LP, Hemming VG, Longfield R, Valdes-Dapena AA, Lopreiato JO: Avoidance of false-negative blood culture results by rapid detection of pneumococcal antigen. JAMA 1984, 252:17421743.

33. Razin S: DNA probes and PCR in diagnosis of mycoplasma infections. Mol Cell Probes 1994, 8:497-511.

34. Oberst RD, Hays MP, Bohra LK, Phebus RK, Yamashiro CT, PaszkoKolva C, Flood SJ, Sargeant JM, Gillespie JR: PCR-based DNA amplification and presumptive detection of Escherichia coli 0157:H7 with an internal fluorogenic probe and the $5^{\prime}$ nuclease (TaqMan) assay. Appl Environ Microbiol 1998, 64:3389-3396.

35. Bieche I, Olivi M, Champeme MH, Vidaud D, Lidereau R, Vidaud M: Novel approach to quantitative polymerase chain reaction using real-time detection: application to the detection of gene amplification in breast cancer. Int J Cancer 1998, 78:661-666.

36. Laurendeau I, Bahuau M, Vodovar N, Larramendy C, Olivi M, Bieche I, Vidaud M, Vidaud D: TaqMan PCR-based gene dosage assay for predictive testing in individuals from a cancer family with INK4 locus haploinsufficiency. Clin Chem 1999, 45:982-986.

37. Mensink E, van de Locht A, Schattenberg A, Linders E, Schaap N, Geurts van Kessel A, De Witte T: Quantitation of minimal residual disease in Philadelphia chromosome positive chronic myeloid leukemia using real-time quantitative RT-PCR. $\mathrm{Br} J$ Haematol 1998, 102:768-774.

38. Von Ahsen N, Schutz E, Armstrong VW, Oellerich M: Rapid detection of prothrombotic mutations of prothrombin (G20210A), factor V (G1691A) and methylenetetrahydrofolate reductase (C677T) by real-time fluorescence PCR with the LightCycler. Clin Chem 1999, 45:694-696.

39. Lewin SR, Vesanen M, Kostrikis L, Hurley A, Duran M, Zhang L, Ho $\mathrm{DD}$, Markowitz M: Use of real-time PCR and molecular beacons to detect virus replication in human immunodeficiency virus type 1infected individuals on prolonged effective antiretroviral therapy. $J$ Virol 1999, 73:6099-6103.

40. Pahl A, Kuhlbrandt U, Brune K, Rollinghoff M, Gessner A: Quantitative detection of Borrelia burgdorferi by real-time PCR. J Clin Microbiol 1999, 37:1958-1963.

41. Martell M, Gomez J, Esteban JI, Sauleda S, Quer J, Cabot B, Esteban $R$, Guardia J: High-throughput real-time reverse transcription-PCR quantitation of hepatitis C virus RNA. J Clin Microbiol 1999, 37: 327-332.

42. Kimura H, Morita M, Yabuta $Y$, Kuzushima K, Kato K, Kojima S, Matsuyama T, Morishima T: Quantitative analysis of Epstein-Barr virus load by using a real-time PCR assay. J Clin Microbiol 1999, 37: 132-136.

43. Doern G, Vautour R, Gaudet M, Levy B: Clinical impact of rapid in vitro susceptibility testing and bacterial identification. J Clin Microbiol 1994, 32:1757-1762.

44. Barenfanger J, Drake C, Kacich G: Clinical and financial benefits of rapid bacterial identification and antimicrobial susceptibility testing. J Clin Microbiol 1999, 37:1415-1418.

Authors' affiliations: Jean-Paul Pirnay, Luc Duinslaeger, Pascal Reper, Christian Vandenvelde and Alain Vanderkelen (Burn Wound Centre, Queen Astrid Military Hospital, Neder-Over-Heembeek, Belgium), JeanPaul Pirnay, Daniel De Vos and Pierre Cornelis (Laboratory of Microbial Interactions, Department of Immunology, Parasitology, and Ultrastructure, Flanders Interuniversity Institute of Biotechnology, Vrije Universiteit Brussel, Sint-Genesius-Rode, Belgium), and Daniel De Vos (Wound Healing Department, Innogenetics, Neder-Over-Heembeek, Belgium)

Correspondence: Jean-Paul Pirnay, Burn Wound Centre, Queen Astrid Military Hospital, Bruynstraat 1, B-1120 Neder-Over-Heembeek, Belgium. Phone: +32 (0)2 264 5182; fax: +32 (0)2 264 4833; e-mail: skinbank@hmra.smd.be 